Copying. This journal is registered with the Copyright Clearance Center, 222 Rosewood Drive, Danvers, MA 01923, USA. Organizations in the USA who are also registered with CCC may therefore copy material (beyond the limits permitted by sections 107 and 108 of US copyright law) subject to payment to CCC of the per copy fee of $\$ 16.00$. This consent does not extend to multiple copying for promotional or commercial purposes. Code 0954-1020/2011 \$16.00. ISI Tear Sheet Service, 3501 Market Street, Philadelphia, PA 19104, USA, is authorized to supply single copies of separate articles for private use only.

Organizations authorized by the Copyright Licensing Agency may also copy material subject to the usual conditions.

For all other use, permission should be sought from Cambridge University Press.

This journal issue has been printed on FSC-certified paper and cover board. FSC is an independent, non-governmental, notfor-profit organization established to promote the responsible management of the world's forests. Please see www.fsc.org for information.

Printed in the UK by Cambridge University Press. 


\section{A science}

\section{Volume $23 \quad$ Number $6 \quad 2011$}

\section{CONTENTS}

Editorial

\section{REVIEW}

Management of Antarctic baleen whales amid past exploitation, current threats and complex marine ecosystems

Rebecca LeAper \& CARA MiLler

\section{BIOLOGICAL SCIENCES}

Archaeal diversity revealed in Antarctic sea ice Rebecca O.M. Cowie, Elizabeth W. Maas \& KEN G. RYAN

Untouched Antarctica: mapping a finite and diminishing environmental resource

Kevin A. Hughes, Peter Fretwell, Joanna Rae, Keith Holmes \& ANDREw Fleming

Thermophilic bacteria present in a sample from

Fumarole Bay, Deception Island

Patricio A. Muñoz, Patricio A. Flores,

Freddy A. Boehmwald \& JenNy M. Blamey

Carbon dioxide emissions of Antarctic tourism

RAMON FARRENY, JoRdi OliVER-SOLÀ,

MACHIEl LAMERS, BAS AMELUNG,

Xavier Gabarrell, JoAn RiERAdeVALl,

MARTÍ BOADA \& JAVIER BENAYAS

Dispersal and dispersion of southern elephant seals in the Kerguelen province, Southern Ocean

W. Chris Oosthuizen, Marthán N. Bester,

Cheryl A. Tosh, Christophe Guinet,

DOMINIQUE BESSON \&

P.J. NICO DE BRUYN
Alkanes and polycyclic aromatic hydrocarbons in marine surficial sediment near Antarctic stations at Fildes

Peninsula, King George Island

Margarita Préndez, Carolina Barra,

Carla Toledo \& Pablo Richter

Interannual variability of net community production and air-sea $\mathrm{CO}_{2}$ flux in a naturally iron fertilized region of the Southern Ocean (Kerguelen Plateau) Marie Paule Jouandet, Stephane Blain, Nicolas Metzl \& Mathieu Mongin

\section{EARTH SCIENCES}

Calcareous dinoflagellate cysts from the Pleistocene (Marine Isotope Stage 31) of the Ross Sea, Antarctica Michael Streng, Oliver Esper \& Jutta Wollenburg

Short Note: New data on morphology of late Eocene penguins and implications for their geographic distribution PIOTR JADWISZCZAK

\section{PHYSICAL SCIENCES}

High-frequency observations of $\mathrm{pH}$ under Antarctic sea ice in the southern Ross Sea

PAul G. Matson, Todd R. Martz \&

GRETCHEN E. HoFMANN

Decadal variability of winter temperatures in the Antarctic Peninsula region V.O. KravchenKo, O.M. EvtushevsKy, A.V. GrytsaI \& G.P. MILINEVSKY

Bromoform concentrations in slush-layer water in Antarctic fast ice DAIKI Nomura, Atsushi OOKI, DAISUKe SimizU

\section{Cambridge Journals Online} For further information about this journal please go to the journal website at: journals.cambridge.org/ans

\section{CAMBRIDGE} UNIVERSITY PRESS 